УДК 331.5:364.2

DOI: https://doi.org/10.37320/2415-3583/9.20

Богуш Л.Г.

кандидат економічних наук, старший науковий співробітник, Інститут демографії та соиіальних досліджень імені М.В. Птухи Національної академії наук України ORCID: https://orcid.org/0000-0001-6196-3781

\title{
НЕСТАНДАРТНА ЗАЙНЯТІСТЬ У КОНТЕКСТІ ДОТРИМАННЯ СОЦІАЛЬНО-ТРУДОВИХ ПРАВ
}

Досліджено проблематику та підходи до регулювання нестандартних трудових відносин, які в останні два десятиріччя стрімко поширюються в Украӥні, у контексті дотримання соціально-трудових прав формально $і$ неформально зайнятих. Інтерес бізнес-спільноти до здешевлення кадрових ресурсів виробництва та підвищення ефективності експлуатації виробничої бази перетворив позикову прачю на невід'ємний чинник сучасної глобалізованої економіки. Водночас явище нестандартних трудових відносин у країнах, щчо розвиваються, характеризується спектром мультиплікованих негативів, пов 'язаних із сочіальним демпінгом, зниженням рівня й якості життя найманих працівників, погіршенням практики реалізації унормованих сочіально-трудових гарантій, розширенням тіньового сектору національних господарств, зростанням необтрунтованої сочіальної нерівності.

Ключові слова: нестандарті трудові відносини, позикова прачя, ринок праиі, соиіально-трудові права зайнятих, нормативно-правове регулювання.

Постановка проблеми. Послідовне входження економіки України в дедалі ширший спектр транснаціональних господарських та інших видів міжнародних відносин у глобалізованому світі, опосередковуючись особливостями поточного етапу науково-технічного прогресу у сфері організації виробництва, професійних і загалом соціальних комунікацій, стимулює ствердження, урізноманітнення форм та розширення масштабів нестандартних трудових відносин як механізму задоволення кадрових потреб підприємств.

Інтерес бізнес-спільноти до використання потенціалу нестандартних трудових відносин як чинника здешевлення кадрових ресурсів виробництва та підвищення ефективності експлуатації виробничої бази перетворив регульовану ними позикову працю на невід'ємний чинник сучасної глобалізованої економіки. Водночас значне поширення нестандартної зайнятості в Україні в умовах динамічних суспільно-економічних змін та послідовної інтеграції у світове господарство супроводжується численними ускладненнями й негараздами 3 дотриманням соціально-трудових прав формально і неформально зайнятих.

Аналіз останніх досліджень i публікацій. Серед фахових напрацювань, які висвітлюють теорію і практику нестандартної зайнятості, у контексті ствердження й розширення відповідного сегменту соціально-трудових відносин в Україні доцільно передусім відзначити роботи щодо:

- обгрунтування засад регулювання позикової праці з використанням досвіду країн і макрорегіонів, що розвиваються, та провідних постіндустріальних економік [1-6];

- темпів, особливостей, проблем поширення спектру різновидів нестандартної зайнятості в
Україні в умовах глобалізації ключових тенденцій та асиметрій розвитку національних ринків праці [2-10];

- найгостріших протиріч дотримання соціально-трудових прав вітчизняної позикової робочої сили в період фінансово-економічної нестабільності та хаотичних спроб масштабних динамічних змін трудового законодавства $[2 ; 3 ; 6 ; 7 ; 9 ; 10]$.

Зазначені фахові дослідження [1-10] під нестандартними (або нестійкими, атиповими, гнучкими) трудовими відносинами та відповідними формами зайнятості, що організуються на ïх основі, розуміють практику найму суб'єктами господарювання працівників для подальшого виконання ними роботи в іншого роботодавця. Указані форми зайнятості, які активно просуває бізнес-спільнота (насамперед з огляду на потребу зниження виробничих витрат, у т. ч. за рахунок скорочення штатних працівників, обмеження відповідальності за дотримання умов праці й якості трудових відносин), досі залишаються гостро дискусійним на рівні інститутів трипартизму та незадовільно регульованим феноменом світового і національних ринків праці. Найбільш масштабним проявом нестандартної зайнятості стали т. зв. розщеплені (тристоронні) трудові відносини, коли до стандартної схеми «працівник - роботодавець» долучається посередник, організуючи взаємодію зазначених сторін у формі надання позикової праці.

Мета статті полягає у подальшому розкритті питань оцінки нестандартної зайнятості, її переваг та загроз для збалансування національного ринку праці, виявленні чинників і важелів ефективного нормативно-правового та адміністративного регулювання розщеплених трудових відносин за прі- 
оритетом дотримання соціально-трудових прав формально і неформально зайнятих.

Виклад основного матеріалу. За визначенням МОП від 2006 р., термін розщеплених (або тристоронніх) трудових відносин характеризує ситуації, коли працівники, наймані підприємством (постачальником, провайдером), виконують роботи для третьої сторони (користувача, клієнта), якій роботодавець постачає робочу силу або надає послуги [2; 7]. Отже, працівник укладає трудовий договір iз посередником (за суттю, найчастіше приватною агенцією зайнятості чи, за менш поширеною термінологією, рекрутинговою (крюінговою) агенцією, агенцією тимчасової зайнятості, трудовим брокером, внутрішнім підрядником тощо $[1 ; 2])$. Посередник, своєю чергою, укладає із суб'єктом господарювання, який звернувся за послугою, у т. ч. 3 підбору персоналу (тобто кінцевим роботодавцем, що може бути фізичною чи юридичною особою [11]), цивільно-правову угоду про т. зв. поставку, оренду, лізинг персоналу, за яким отримує прибуток у формі комісійних. У результаті відбувається розщеплення функції роботодавця між фактичним кінцевим користувачем і юридичним роботодавцем (агенцією-посередником), унаслідок чого трудові відносини між економічно активною особою, яка найнята агенцією зайнятості, та кінцевим роботодавцем часто жодним договором не регламентуються; розширення штату підприємства-користувача не відбувається. Саме опосередкованість в ідентифікації роботодавця фахівці Бюро МОП із діяльності робітників (ACTRAV) вважають генератором спектру проблем нестандартної занятості в країнах світу [2].

У результаті виникають трудові відносини, у рамках яких: право розпорядження своєю робочою силою переходить від працівника до агенції - надавача послуг позикової праці; робоча сила набуває властивостей звичайного товару, вилучається зі спеціалізованого ринку праці i включається в загальний обіг товарів, робіт та послуг (стає суб'єктом цивільно-правового регулювання); умови купівлі-продажу власної робочої сили визначає не працівник, а угода компаній постачальника і користувача (провайдера і клієнта).

Організація нестандартної зайнятості та розщеплених трудових відносин у ऑii межах із наданням позикової праці та послуг тимчасових працівників найчастіше відбувається у формі аутсорсингу, аутстаффінгу, підряду, лізингу персоналу. Цей перелік послідовно поповнюється (останнім часом спостерігається поширення компаній 3 temporary staffing), адже в умовах глобалізації світової економіки та техніко-технологічних інновацій розщеплені трудові відносини є доволі динамічним феноменом, набуваючи широкого спектру організаційних форм під впливом вироб- ничої специфіки, територіальних соціально-економічних умов, особливостей нормативно-правового регулювання.

Під аутсорсингом зазвичай прийнято розуміти передачу організаціям-посередникам виконання тих функцій, які не належать до основної діяльності підприємства (зазвичай функцій бухгалтерського і кадрового обліку, аудиту, охорони та інших аспектів дотримання безпеки, транспортного, складського, юридичного, рекламного обслуговування, управління інформаційними системами, перекладу, прибирання приміщень, забезпечення інших допоміжних аспектів функціонування офісу) $[1 ; 8 ; 10]$. На відміну від разових (епізодичних, випадкових) сервісних послуг на аутсорсинг зазвичай передають функції з підтримки працездатності й роботи окремих підрозділів та інфраструктури підприємства-замовника, що регламентує доволі тривала угода (зазвичай терміном не менше року) [9]. При цьому штатних співробітників, які виконували таку роботу до започаткування співробітництва з аутсорсинговою компанією, або переводять до неї, або скорочують, економлячи на оплаті праці.

Більш уразливою в контексті дотримання соціально-трудового законодавства формою запозиченої праці вважають аутстаффінг персоналу, який на практиці часто полягає у переведенні частини штатних працівників підприємства у статус позаштатних завдяки передачі їх у штат кадрової агенції [10]. Загалом аутстаффінг $\epsilon$ механізмом підбору та управління персоналом, що грунтується на відсутності безпосередніх правових відносин (цивільно-правових, трудових) між замовником та працівниками, які направляються агенцією-посередником для надання певних послуг або проведення робіт за місцем знаходження замовника $[1 ; 8]$.

Визначаючи відмінні та спільні риси аутсорсингу й аутстаффінгу, зазвичай підкреслюють, що договір аутсорсингу унормовує прийом працівників у штат аутсорсингової компанії, особливості нарахування їм заробітної плати, інших передбачених трудовим законодавством виплат, а також умови надання їх організації-замовнику для участі у виробничому процесі, управлінні виробництвом або для виконання пов'язаних із цим функцій. Такі позикові кадри можуть працювати на компанію-замовника у їі офісах або дистанційно - на робочому місці, наданому посередником (юридичним роботодавцем), удома тощо. Отже, аутсорсинг також може характеризуватися повною відсутністю зв'язку між замовником послуг і персоналом як їх безпосереднім виконавцем. При цьому, як і в рамках угод аутстаффінгу, замовник оплачує вартість отриманих послуг агенції-посереднику, що надала працівників зі свого штату та зобов'язана сплачувати податки, 
відрахування до фондів соціального страхування й інші обов'язкові за трудовим законодавством платежі [1; 7-9].

Низка фахівців критично ставиться до застосування в характеристиці нестандартної зайнятості, розщеплених трудових відносин та позикової праці терміну лізингу персоналу, наголошуючи на принциповій відмінності людських та уречевлених ресурсів виробництва, як і підходів до їх капіталізації, а отже, на морально-етичних аспектах зведення статусу найманого працівника до рівня основних фондів. Лізингова угода допускає можливість переходу права власності на об'єкт лізингу від лізингодавця до лізингоотримувача; отже, придбання у власність основних фондів, що беруться на баланс підприємства, та прийом у штат працівника мають різну юридичну природу [1].

Водночас під лізингом персоналу часто розуміють традиційні послуги агенцій зайнятості (а саме організацію тимчасової зайнятості, надання тимчасового персоналу) [7]. Принципову відмінність лізингу персоналу від аутстаффінгу вбачають у тому, що за умовами угоди із забезпечення цієї послуги розрив відносин працівника 3 користувачем призводить до припинення відносин також i 3 посередником, у штаті якого працівник оформлений, тоді як згідно з умовами послуги лізингу персоналу трудові відносини із лізингодавцем зберігаються [7; 9].

Вагомою перепоною на шляху рекрутингу тимчасового персоналу (тобто потрібного на неповний робочий день чи на короткостроковий від одного дня до кількох місяців - період) безпосередньо роботодавцями слугує невизначеність часу на пошук необхідного фахівця в конкретному місці. Ефективним шляхом вирішення проблеми $є$ звернення із запитом до компаній-посередників (окремих агенцій із temporary staffing або компаній аутсорсингу, переважна більшість яких відносить цю послугу до профільних [7]), які акумулюють бази даних щодо пропозиції такої праці, надаючи відомості потенційному роботодавцю на власних умовах. Підбір такого персоналу здійснюється швидко (часто впродовж кількох годин).

Якщо аутсорсинг, аутстаффінг і лізинг персоналу передбачають більш довготермінові відносини між роботодавцем і співробітником (на період від місяця і більше), а під час розрахунків оплати праці використовується іiі місячна ставка, то послуги temporary staffing оплачуються лише погодинно.

Як свідчать зарубіжний досвід та започаткована вітчизняна практика, характерними прикладами temporary staffing $є$ підбір кадровими агенціями за запитами підприємств і організацій секретарів та бухгалтерів (наприклад, для підготовки та проведення річних звітних заходів), персоналу для обслуговування спеціальних про- єктів (презентацій, конференцій, виставок та ін.), а також переїздів і ремонтних робіт, касирів для крупних торговельних закладів (супермаркетів та ін.) у години пік, реалізаторів сезонної продукції від виробника (морозива, напоїв тощо).

Загалом зазначені форми надання послуг iз підбору персоналу за змістом є управлінськими технологіями, які дають змогу суттєво економити в процесі повноцінного забезпечення трудовими ресурсами бізнес-процесів окремих виробництв, компаній, консорціумів, використовуючи послуги посередницьких (рекрутингових, аутсорсингових, аутстафінгових) організацій. За оцінками, у деяких крупних (у т. ч. транснаціональних) компаніях до 80\% вартості кінцевої продукції в останні 10-15 років становить додана вартість, утворена працею персоналу, взятого в позику в різних організаційних формах і на різні терміни [7]. У підсумку в масштабах країни, внутрішньодержавних і транскордонних регіонів це дає змогу суттєво підвищувати мобільність персоналу як окремих підприємств, організацій, так і сукупної робочої сили, прискорювати та оптимізувати процеси перерозподілу трудових ресурсів за ланками економіки і територіальними господарськими комплексами.

Поряд із задоволенням виробничих потреб лізинг персоналу, аутсорсинг i temporary staffing виконують важливу соціальну функцію, організуючи тимчасові робочі місця та нестабільну (сезонну) зайнятість для фахівців вузьких спеціалізацій та безробітних спеціалістів найвищої кваліфікації з високими запитами щодо оплати праці, малозабезпечених, низькокваліфікованих, уразливих верств населення (зокрема, передпенсійного віку), осіб в оплачуваних і неоплачуваних відпустках по догляду за дітьми, студентів, безробітних випускників вищих і професійно-технічних навчальних закладів, учнівської молоді. Якщо для першої категорії зайнятих із високою кваліфікацією, що користується попитом, реалізується перспектива отримання стабільних доходів від роботи над проєктами (короткими та довготерміновими) для різних організацій, то для решти пропозиція послуг у сфері позикової праці відкриває можливості здобуття перших робочих місць, підробітків у вільний час, певного початкового професійного досвіду, доволі затребуваного під час відбору претендентів на вакансії у штатах рейтингових вітчизняних та іноземних компаній.

До основних переваг поширення практики використання позикової праці відносять:

- можливості коригування ризиків кінцевих роботодавців (користувачів), пов'язаних із попитом на продукцію, піками і спадами виробництва, перспективами його диверсифікації, що суттєво впливають на динаміку ресурсоємності та інвестиційної привабливості суб'єктів господарювання - від окремих підприємств до консорціумів; 
- запровадження технологій гнучкого використання робочого часу як окремих економічно активних осіб, так і суб'єктів господарювання;

- перспективи модернізації системи управління трудовими відносинами та сферою зайнятості згідно 3 ринковою кон'юнктурою (серед іншого - розширення пропозиції робочих місць у легальному секторі національного господарства);

- підвищення рівня зайнятості безробітних; реалізацію попиту на працю за сумісництвом та у вільний від основної діяльності час (фахівців вузьких спеціалізацій та сезонних видів економічної діяльності, низькокваліфікованих працівників широкого профілю, молоді, осіб у відпустках по догляду за дитиною, осіб передпенсійного і пенсійного віку тощо);

- детінізацію вагомої частки фактичних трудових відносин із вітчизняними та іноземними суб'єктами господарювання на території України, легалізацію фактичного рівня оплати праці, нарощування фіскальних відрахувань та виплат до фондів соціального страхування.

Складна суспільно-економічна ситуація в Україні, зокрема низький рівень життя та перманентна загроза безробіття широких верств, спонукає як найбільш конкурентоспроможних, так i низькокваліфікованих економічно активних громадян до роботи та їі пошуку в умовах підвищених ризиків (у т. ч. відсутності гарантій соціального захисту, тіньових форм оплати праці, фактичного ігнорування правил безпеки). У цих умовах проблематика регулювання діяльності суб'єктів господарювання (вітчизняних та іноземних), що організують пропозицію послуг позикової праці та її використовують, охоплює:

- унормування та підвищення ефективності контролю над діяльністю відповідних компаній;

- детінізацію цього сегменту ринку зайнятості, зокрема завдяки оптимізації практики ліцензування спектру посередників у сфері рекрутингу;

- забезпечення соціального захисту зайнятих у рамках повноважень державних органів регулювання умов та безпеки праці (гостро актуальними аспектами їх соціального захисту є дотримання обгрунтованої тривалості робочого дня, гідного рівня оплати праці, наявність соціального пакету, ефективність механізмів убезпечення спектру умов праці);

- підвищення ефективності співпраці з відповідних питань представників працівників та роботодавців, а також органів влади.

Загалом серед основних недоліків практики позикової праці, що грунтуються на низькому рівні участі або й відстороненні працівника від визначення умов купівлі-продажу власної робочої сили на користь агенції зайнятості, слід відзначити:

- порушення трудового законодавства з боку як кадрових агенцій, так і організацій, що використову- ють позикову працю, які проявляються у відмінностях в умовах праці на однакових посадах певного підприємства цих працівників і штатно зайнятих (насамперед ii оплаті; режимі - понадурочно, у вихідні дні; можливості й тривалості відпочинку; доступності переходу до виконання інших трудових функцій та обов' язкового соціального страхування), а також у погіршенні гарантій зайнятості позикових працівників (укладання строкових трудових (або цивільно-правових) договорів замість постійних колективних трудових договорів 3 усіма прийнятими нормами захисту та пільгами, що можуть бути припинені в разі відмови підприємства-користувача від послуг агенції-посередника);

- розпливчатість сфери відповідальності за умови праці, іiі охорону, дотримання техніки безпеки з боку агенції-посередника та підприємствакористувача;

- необгрунтоване суттєве зниження або й ухиляння від витрат на навчання та підвищення кваліфікації персоналу на виробництві;

- відсутність перспектив підвищення рівня оплати праці у конкретного роботодавця-користувача, що розраховує їі обсяг, виходячи з окладу та фактично відпрацьованого часу;

- часту практику істотного зниження обсягів або ухиляння від відрахувань до фондів соціального страхування, що мають витрачатися на виплати позиковим працівникам, які постраждали на виробництві, отримали профзахворювання, або їх сім'ям (у разі загибелі працівника), а також на виплату пенсій цій категорії зайнятих;

- загрози зниження рівня та якості життя, економічної та професійної деградації зайнятих позиковою працею (погіршення якості робочої сили через брак умов для самонавчання, розширення сфери досвіду та підвищення кваліфікації; скорочення платоспроможного попиту внаслідок нерівних умов оплати праці позикових працівників і штатно зайнятих; неритмічність надходжень до бюджетів домогосподарств позикових працівників, а отже, нестабільність їх витрат);

- соціальний демпінг, що насамперед проявляється через: використання тимчасово зайнятих як штрейкбрехерів у протидії боротьбі працівників за трудові й соціально-економічні права, створюючи загрози зайнятості постійних працівників; збільшення неоплачуваного виробничого навантаження останніх у зв'язку з помітною плинністю тимчасово зайнятих та необхідністю їх первинної професійної орієнтації і навчання;

- розпливчатість механізму і методик розрахунку страхового стажу та пенсійних виплат за позикову найману працю, сумнівну доступність більш раннього виходу на пенсію для цієї категорії зайнятих;

- становлення схем порушення фіскального законодавства, заснованих на декларуванні для 
оподаткування лише контингенту штатних працівників, без урахування виведених за штат на засадах аутсорсингу, аутстаффінгу, а також використання позикової праці у формі temporary staffing.

Отже, порівняно зі штатними працівниками підприємства-користувача позикові працівники часто скеровуються на роботи 3 гіршими умовами праці, нестабільним трудовим режимом та нижчою заробітною платою, що не відшкодовує вимушених (з ініціативи роботодавця) простоїв, понаднормових робіт та не компенсує небезпек виробничого середовища. Як правило, їм не надається відпустка, у т. ч. додаткова - за шкідливі умови праці.

Загалом між агенцією зайнятості та позиковим працівником складаються доволі непрозорі стосунки. Поряд із відсутністю або фрагментарністю колективного договору агенції зайнятості з позиковими працівниками, відсутністю профспілкових організацій, що захищають права цієї категорії зайнятих (створити їх надзвичайно складно, зважаючи на роз'єднаність працівників), нерозробленістю механізмів взаємодії агенційпосередників із представниками працівників спостерігається тяжіння діяльності у сфері позикової праці до тінізації та корумпованості. Насамперед, це стосується вітчизняної та іноземної практики лізингу, аутсорсингу й temporary staffing висококваліфікованого персоналу вузьких спеціалізацій у сферах транскордонних транспортних і логістичних послуг пасажиро- й вантажоперевезень. Наймання таких фахівців (зокрема, членів екіпажів літальних і судноплавних засобів) доволі часто супроводжується незаконними поборами крюінгових агенцій та безвідповідальністю роботодавців-користувачів за соціально-правовий захист позикових працівників.

У більшості країн світу антидискримінаційне законодавство забороняє коригувати рівень оплати праці зайнятих на співставних посадах залежно від їхніх статі, раси, віросповідання. Водночас, як свідчить світова статистика, якщо компанія практикує використання позикової праці, контингент таких позаштатних працівників переважно складається 3 жінок чи представників національних i расових меншин [2]. Останній чинник не лише дає змогу ухилятися від правової відповідальності за невнормовані умови праці, скорочений або практично відсутній соціальний пакет для таких зайнятих, а й, на жаль, доволі часто робить толерантнішою громадську думку щодо їх дискримінації. Яскравими прикладами подібного ставлення до українських легальних i нелегальних транскордонних трудових мігрантів наповнений досвід їх працевлаштування у Польщі, республіках Прибалтики, Росії, інших країнах Східної Свропи.

Скорочення кількості штатних працівників за рахунок масштабного використання позикової праці може також слугувати формальною підставою для спрощеного оподаткування суб'єкта господарювання (наприклад, за фіскальним законодавством для малого бізнесу).

Діяльність МОП щодо правового регулювання нестандартних трудових відносин, зокрема розпочата в 1933 р. із заборони та в подальшому обмеження практики посередництва приватних агенцій на ринку праці, з часом зазнала суттєвої еволюції [1]. Однією з ключових цілей Конвенції № 181 «Про приватні агентства зайнятості», прийнятої в 1997 р., є створення для цих суб'єктів господарювання можливостей функціонування, регульованих пріоритетом захисту працівників, які користуються їхніми послугами [8].

Значну увагу регулюванню розщеплених трудових відносин і нестандартної зайнятості приділяють інституції Свропейського Союзу. На момент затвердження в листопаді 2008 р. Директиви № 2008/104/СС про працю в агенціях тимчасової зайнятості позикову працю було легалізовано в національних законодавствах 15 країн Європи. Високу суспільну оцінку цього документа пов'язують передусім 3 упровадженням принципів рівного ставлення до зайнятих позикової праці та працюючих в умовах звичайних трудових договорів (двосторонніх трудових відносин), а також із наголосом на необхідності забезпечення повноцінного захисту працівників, які винаймаються агенціями тимчасової зайнятості для подальшого надання в користування. Водночас зазначений документ не регулює сукупності прав та обов'язків суб'єктів організації позикової праці, передаючи ці повноваження національним трудовим законодавствам. Зокрема, закріплене право держав - членів СС після проведення консультацій із соціальними партнерами профспілками та об'єднаннями роботодавців на національному і галузевому рівнях укладати акти соціального діалогу, в яких можуть передбачатися винятки з принципу рівного ставлення (передусім щодо коштів, виплачуваних агенціями зайнятості позиковим працівникам у періоди між їх роботою на підприємствах-користувачах) [1;8].

На жаль, попри тривалий досвід регулювання, фахівці МОП та експерти 3 трудового права Німеччини, зокрема, зазначають, що у цій та інших західних країнах, де позикова праця легалізована вже тривалий час, спостерігаються яскраві прояви соціального демпінгу, адже поширення цієї форми зайнятості не сприяє створенню нових робочих місць, спричиняючи переродження вже існуючих (досі оцінюваних як якісні, з гідними умовами праці) на менш соціально захищені й безпечні, низькооплачувані [8]. Проведені в останні роки дослідження Свропейського фонду поліпшення умов життя і праці засвідчили, що позикові працівники потерпають від гірших умов 
і особливо від нижчої оплати праці навіть там, де закон вимагає для них рівності зі штатними працівниками [2]. Трудову діяльність (а відповідно, спосіб, рівень, якість життя) позикових працівників визнають значно нестабільнішою, ніж унормовану традиційними двосторонніми трудовими відносинами (у Франції, наприклад, середня тривалість роботи позикового працівника становить лише два тижні) [1;8].

Важливим механізмом формування, актуалізації та реалізації державної політики у сфері позикової праці, як засвідчує міжнародна практика, $\epsilon$ функціонування структур інспекції праці, діяльність яких в Україні дедалі потребує підвищення ефективності згідно з вимогами МОП [4].

Загалом вітчизняна сфера нестандартної зайнятості в останні півтора десятиріччя стрімко еволюціонує, у низці суттєвих аспектів досі перебуваючи поза законодавчим урегулюванням. Чинне вітчизняне законодавство нині містить лише обриси сфери регулювання позикової праці осіб, які укладають трудовий договір із приватним агенціями зайнятості.

Запроваджені в 2013 р. зміни до ст. 39 Закону України «Про зайнятість населення» фактично започаткували системне врегулювання правовідносин, які виникають під час здійснення діяльності суб'єктів господарювання, які організують позикову працю. Як регламентує Порядок видачі дозволу на наймання працівників для подальшого виконання ними роботи в Україні в іншого роботодавця, затверджений Постановою КМУ від 20.05.2013 № 359 на виконання зазначених законодавчих змін, який досі не набрав чинності, коло таких суб'єктів господарювання нині визначається виходячи 3 їхніх установчих документів та щодо обмеженого переліку видів економічної діяльності. Серед них - діяльність агентств працевлаштування; діяльність агентств тимчасового працевлаштування; інша діяльність із забезпечення трудовими ресурсами [12] (а отже, фактично весь можливий спектр послуг позикової праці). Конвенцію МОП № 181 «Про приватні агентства зайнятості» в Україні також поки не ратифіковано.

Масштаби поширення практики розщеплених трудових відносин і нестандартної зайнятості в легальному і тіньовому секторах економіки України визначаються іiі структурою, спеціалізацією в міжнародному поділі праці, експортним потенціалом окремих видів економічної діяльності та його динамікою. Доволі широкий ринок позикової праці вже склався у добувній та гірничопереробній, металургійній, хімічній і нафтохімічній промисловості, аграрному секторі (інтенсивному сільському господарстві та сезонних агропереробних ланках), сфері транспортних послуг (насамперед, у вантажоперевезеннях), роздрібній торгівлі.
За оцінками експертів, закріплення у 2007-2009 рр. тенденції щодо виведення існуючого персоналу підприємства-користувача за штат (у процесі його реорганізації, реструктуризації, перепрофілювання, приватизації, порушення справи про банкрутство, ліквідації) стало наслідком останніх світових фінансово-економічних криз та визначило домінуючу роль цієї форми організації нестандартних трудових відносин у вітчизняній практиці $[2 ; 7 ; 9 ; 10]$. За даними Федерації профспілок, уперше переведення частини працівників обслуговуючих видів діяльності в статус позикових у процесі реорганізації промислового виробництва відбулося в Україні в 2003 р.

Висновки. Підсумовуючи сказане, слід відзначити, що, зважаючи на зміст дискусій і застережень спільнот науковців та представників зайнятих, обопільно корисними для економічно активного населення й роботодавців сферами застосування позикової праці є:

- лізинг та аутсорсинг персоналу (основного, обслуговуючого), який має постійний або строковий трудовий договір із роботодавцем за основним місцем роботи, на користь іншої компанії, що потребує послуг за профілем, надання яких здебільшого оформляється цивільно-правовою угодою;

- влаштування через агенції зайнятості на тимчасову роботу осіб, які шукають додаткових доходів та підробітків (малозабезпечених, членів багатодітних сімей, студентів та учнівської молоді, осіб з інвалідністю, громадян передпенсійного і пенсійного віку тощо). Більш дискусійним аспектом залишається можливість участі рекрутингових компаній в організації оплачуваних громадських робіт із залученням низки соціально вразливих верств (наприклад, безробітних, що перебувають на обліку служб зайнятості понад рік, громадян, які повернулися 3 місць позбавлення волі);

- тимчасове працевлаштування осіб на робочі місця, які, згідно із законодавством, мають зберігатися за штатними працівниками, відсутніми 3 причин захворювань і травм (у т. ч. професійних та отриманих на робочому місці), перебування у декретній відпустці та відпустці по догляду за дитиною, тривалого службового відрядження;

- організація інноваційної діяльності в рамках розроблення стартапів із використанням кадрового потенціалу близьких за спеціалізацією коворкінгових та венчурних структур.

Разом із тим явище нестандартних трудових відносин у країнах, що розвиваються (у т. ч. в Україні), характеризується спектром потужних мультиплікованих негативів, пов'язаних із проявами соціального демпінгу, зниженням рівня й якості життя найманих працівників, погіршенням практики реалізації унормованих соціально-тру- 
дових гарантій, розширенням тіньового сектору національних господарств, зростанням необгрунтованої соціальної нерівності.

Як свідчить зарубіжна і менш тривала вітчизняна практика, нестабільність загальних суспільно-економічних умов суттєво ускладнює умови та якість соціального діалогу в регулюванні позикової праці на окремому підприємстві-користувачі та в державі у цілому, що проявляється в жорсткішій позиції роботодавців - юридичних i фактичних - iз питань забезпечення спектру соціально-трудових прав найманого персоналу. Проблеми захисту прав позикових працівників, роботодавцем яких визнається агенція зайнятості, є спільними практично для всіх регіонів світу, передусім проявляючись у:

- нестійкості й нетривалості відносин, обмеженості зобов'язань агенції зайнятості перед позиковим працівником, що не дає змоги накопичити достатній безперервний стаж (як обов'язковий у контексті доступу до пенсійного забезпечення, інших важливих соціальних гарантій), утворити професійне об'єднання (У т. ч. здатне посприяти в забезпеченні стабільності графіку оплати праці та виплат за вимушені виробничі простої);

- двозначності трактовок, зловживаннях, ухилянні кінцевих роботодавців від відповідальності за якість соціально-трудових відносин (у т. ч. завдяки виведенню працівників за штат);

- надмірній деталізації трудового права та суміжних сфер законодавства в умовах значно меншої спроможності пересічного працівника до його тлумачення, обмеженості доступу останнього до кваліфікованої юридичної допомоги (у т. ч. через менші фінансові ресурси для участі в судочинстві).

Серед актуальних пріоритетів у сфері регулювання нестандартних трудових відносин в Україні слід відзначити:

1) у сфері профільного унормування трудового законодавства:

- подальше врегулювання в спектрі законів про працю засад і практики реалізації норм, що визначають загальні умови діяльності суб'єктів господарювання, які наймають працівників для подальшого виконання ними роботи у іншого роботодавця (зокрема, на засадах спеціального трудового договору, який має усувати ознаки й запобігати розпорядженню особою як об'єктом);

- удосконалення механізмів захисту прав зайнятих на гідні умови, режим та оплату праці у разі фактичного вступу в трудові відносини, оформлені як строковим трудовим, так і цивільноправовим договором;

- посилення відповідальності роботодавця за соціальну результативність кадрової політики підприємства з урахуванням законодавчо визначених індикаторів національної безпеки;
- ратифікацію Конвенції МОП № 181 «Про приватні агентства зайнятості», приведення вітчизняної нормативно-правової бази у відповідність 3 її основними принципами та вимогами;

- обмеження можливостей ухиляння роботодавців (вітчизняних і зарубіжних) від надання позиковим працівникам соціально-трудових гарантій; опрацювання механізму обов'язкового соціального діалогу як складової частини процесу залучення позикової праці на підприємствах, що змінюють форму власності, власника, організаційні підходи до ведення основних та допоміжних видів господарювання;

- приведення профільного законодавства у відповідність до потреб розвитку малих та середніх суб'єктів господарювання, підходи до використання позикової праці якими мають суттєві відмінності від практики крупних виробництв (для останніх в Україні нормативно-правову базу зазвичай прийнято пристосовувати в першу чергу);

- вирівнювання правового становища позикових працівників-співвітчизників (у т. ч. тих, хто вступає у трудові відносини із суб'єктами господарювання інших держав) та іноземців, що вступають у трудові відносини на території України;

- посилення відповідних контрольно-наглядових і превентивних функцій системи інспекції праці;

2) у сфері забезпечення гідних умов праці та фіскальної дисципліни на конкретних підприємствах:

- подальше унормування, посилення контролю над діяльністю 3 ліквідації зарплатних виплат «у конвертах», упровадження ефективних адміністративних механізмів подолання практики внесення до трудових договорів і строкових контрактів вимоги щодо нерозголошення розміру оплати праці;

- запровадження методик відстеження практики формального зниження рівня оподаткування суб' єктів господарювання внаслідок виведення частини працівників за штат (у т. ч. за спрощеними схемами малого бізнесу), моніторинг і профілактика такої незаконної діяльності;

3) у сфері оптимізації інспекції праці в Україні:

- підвищення соціального статусу, забезпечення об' єктивного наповнення повноважень державних інспекторів праці (як підставу для оптимізації їх штатів і трудового навантаження);

- підвищення ефективності механізмів співпраці органів влади та судочинства у реалізації приписів територіальних органів інспекції праці;

- удосконалення програм підготовки та підвищення кваліфікації державних інспекторів праці в галузях бухгалтерських, економічних, інженерних, юридичних, психологічних, медичних знань. 


\section{Список використаних джерел:}

1. Лагутіна І.В. Міжнародно-правове регулювання діяльності приватних агентств зайнятості. Альманах міжнародного права. Вип. 8. С. 130-137. URL : http://intlawalmanac.net/v8/18.pdf (дата звернення: 27.12.2019).

2. Курзіна M. Захист прав робітників в умовах розповсюдження позикової праці: перспективи для України. URL : https://commons.com.ua/uk/zahist-prav-robitnikiv-v-umovah-rozpo/ (дата звернення: 27.12.2019).

3. Атипичная занятость и прекаризация труда в Украине / под ред. В. Дудина, 3. Поповича. Киев : Центр социальных и трудовых исследований, 2017. 69 с.

4. Біла Г.М. Діяльність інспекцій праці за кордоном: досвід для України. Держава і ринок. C. 134-138. URL : http://www.kbuapa.kharkov.ua/e-book/putp/2011-3/doc/3/03.pdf (дата звернення: 27.12.2019).

5. Легомінова С.В. Сучасний ринок праці України: проблеми та тенденції. Інвестиції: практика та досвід. 2015. № 19. C. 39-43.

6. Юшко А.М. Запозичена праця: проблеми правового регулювання. Право та інновації. 2016. № 1(13). С. 44-52.

7. Коняєва А. Аутсорсинг в Украине: вчера, сегодня, завтра. Кореспондент. 15.03.2011. URL : https://blogs.korrespondent.net/blog/users/3258264-autsorsynh-v-ukrayne-vchera-sehodnia-zavtra (дата звернення: 27.12.2019).

8. Лагутіна I.В. Трудові права позикових працівників. Право $i$ суспільство. 2015. № 5. C. 85-91. URL : http://pravoisuspilstvo.org.ua/archive/2015/5_2015/part_1/17.pdf (дата звернення: 27.12.2019).

9. Новак И., Оверковский Б. Нестандартная занятость в Украине: соииальные риски и контр-стратегии профсоюзов. Киев : Фонд им. Фридриха Эберта (FES), 2011. 24 c. URL : http://www.fes.kiev.ua/new/wb/media/publikationen/2finalnij\%20maket\%20Nestandartna\%20zanyatist.pdf (дата звернення: 27.12.2019).

10. Трошина Т. Нетипові форми зайнятості: ризики для працівників та необхідність правового регулювання. Національна служба посередництва і примирення (відділення в Луганській області). URL : http://nspp-lugansk.ucoz.ua/publ/ netipovi_formi_zajnjatosti_riziki_dlja_pracivnikiv_ta_neobkhidnist_pravovogo_reguljuvannja/1-1-0-20 (дата звернення: 27.12.2019).

11. Конвенція про приватні агентства зайнятості № 181 від 19.06.1997. URL : http://zakon2.rada.gov.ua/laws/ show/993_046 (дата звернення: 27.12.2019).

12. Лист Міністерства соціальної політики України від 26.12.2013 № 14909/0/14-13/06 (витяг). URL : https://www.profiwins.com.ua/uk/letters-and-orders/ministry-of-labor-and-social-policy/4539- (дата звернення: 27.12.2019).

\section{References:}

1. Lahutina I.V. (no data) Mizhnarodno-pravove rehuliuvannia diialnosti pryvatnykh ahentstv zainiatosti [International legal regulation of the private employment agencies' activity]. Almanac of International Law, no. 8, pp. 130-137. Available at: http://intlawalmanac.net/v8/18.pdf (accessed 27 December 2019).

2. Kurzina M. (no data) Zakhyst prav robitnykiv v umovakh rozpovsiudzhennia pozykovoi pratsi: perspektyvy dlia Ukrainy [Protecting the workers' rights in the context of the borrowed labor proliferation: prospects for Ukraine]. Available at: https://commons.com.ua/uk/zahist-prav-robitnikiv-v-umovah-rozpo/ (accessed 27 December 2019).

3. Dudin V., Popovich Z. (eds.) (2017) Atipichnaya zanyatost'i prekarizatsiya truda $v$ Ukraine [Atypical employment and precarization of labor in Ukraine]. Kyiv: Center for Social and Labor Studies. (in Russian)

4. Bila H.M. (no data) Diialnist inspektsii pratsi za kordonom: dosvid dlia Ukrainy [Activity of labor inspectorates abroad: experience for Ukraine]. The State and the Market, pp. 134-138. Available at: http://www.kbuapa.kharkov.ua/e-book/ putp/2011-3/doc/3/03.pdf (accessed 27 December 2019).

5. Lehominova S.V. (2015) Suchasnyi rynok pratsi Ukrainy: problemy ta tendentsii [Modern Ukrainian labor market: problems and trends]. Investment: practice and experience, no. 19, pp. 39-43.

6. Yushko A.M. (2016) Zapozychena pratsia: problemy pravovoho rehuliuvannia [Borrowed labor: problems of legal regulation]. Law and Innovation, no. 1(13), pp. 44-52.

7. Konyaeva A. (2011) Autsorsing V Ukraine: vchera, segodnya, zavtra [Outsourcing in Ukraine: yesterday, today, tomorrow]. Correspondent. Available at: https://blogs.korrespondent.net/blog/users/3258264-autsorsynh-v-ukrayne-vcherasehodnia-zavtra (accessed 27 December 2019).

8. Lahutina I.V. (2015) Trudovi prava pozykovykh pratsivnykiv [Labor rights of borrowed workers]. Law and Society, no. 5, pp. 85-91. Available at: http://pravoisuspilstvo.org.ua/archive/2015/5_2015/part_1/17.pdf (accessed 27 December 2019).

9. Novak I., Overkovskiy B. (2011) Nestandartnaya zanyatost'v Ukräine: sotsial'nye riski i kontr-strategii profsoyuzov [Non-standart work in Ukraine: social risks and counter-strategies of trade unions]. Kyiv: Friedrich Ebert Fund (FES). Available at: http://www.fes.kiev.ua/new/wb/media/publikationen/2-finalnij\%20maket\%20Nestandartna\%20zanyatist.pdf (accessed 27 December 2019).

10. Troshyna T. (no data) Netypovi formy zainiatosti: ryzyky dlia pratsivnykiv ta neobkhidnist pravovoho rehuliuvannia [Atypical forms of employment: risks to employees and the need for legal regulation]. National Mediation and Reconciliation Service (Branch in Luhansk Oblast). Available at: http://nspp-lugansk.ucoz.ua/publ/netipovi_formi_zajnjatosti_riziki_dlja_ pracivnikiv_ta_neobkhidnist_pravovogo_reguljuvannja/1-1-0-20 (accessed 27 December 2019).

11. International Labor Organization (1997) Konventsiia pro pryvatni ahentstva zainiatosti № 181 [Convention on private employment agencies no. 181]. Available at: http://zakon2.rada.gov.ua/laws/show/993_046 (accessed 27 December 2019).

12. Ministry of Social Policy of Ukraine (2013) Lyst vid 26.12.2013 № 14909/0/14-13/06 (vytiah) [Letter dated 26.12.2013 № 14909/0/14-13/06 (extract)]. Available at: https://www.profiwins.com.ua/uk/letters-and-orders/ministry-of-labor-and-socialpolicy/4539- (accessed 27 December 2019). 
Bogush Larysa

Ptoukha Institute for Demography and Social Studies of the National Academy of Sciences of Ukraine

\section{NON-STANDARD EMPLOYMENT IN THE CONTEXT OF COMPLIANCE WITH SOCIAL AND LABOR RIGHTS}

The article examines the problems and approaches to regulation of non-standard labor relations, which have been rapidly spreading in Ukraine in the last 2 decades, in the context of observance of formally and informally employees' social and labor rights. The research methodology involves identifying acute problems of functioning of non-standard employment in Ukraine and justifying approaches to their solution based on the experience of world leading countries and the International Labor Organization recommendations. The interest of the business community in reducing the production resources' cost and improving the production facilities' efficiency has transformed borrowed labor into an integral factor in nowadays globalized economy. At the same time, the phenomenon of non-standard labor relations in developing countries is characterized by a spectrum of multiplied negatives related to social dumping, decreasing in the employees' level and quality of life, worsening of the practice of standardized social and labor guarantees' implementation, widening of the national economies' shadow sector, increasing of unjustified social inequality. Therefore, despite the extensive study of the principles, practices and issues of non-standard employment in the world and national economic literature, there are a number of problems that requires further disclosure. Among them - the assessment of its benefits and threats to balance the national labor market, the identification of the factors and levers for effective legal and administrative regulation of the split labor relations in order to observe the formally and informally employees' social and labor rights. Current priorities for regulation of non-standard labor relations in Ukraine are concentrated around the normalization of labor legislation, ensuring decent working conditions and fiscal discipline at specific enterprises, optimization of national labor inspections. Thus the practical value of the article is determined by the justification of the priority measures to optimize working conditions and living standards of the borrowed employees.

Key words: non-standard labor relations, borrowed labor, labor market, employees'social and labor rights, legal regulation.

JEL classification: J23, J30, J41, K31, D60. 